\title{
Actantial model of Judith, A Key to Unlocking its Possible Purpose: A Greimassian Contribution*
}

\author{
Risimati S. Hobyane (NoRTh-WeSt UniVERSITY)
}

\begin{abstract}
The goal of this article is to investigate the possible purpose of the Greek apocryphal book of Judith. The investigation of the possible purpose of Judith has attracted the interest of many scholars and varying contributions have appeared in this regard. The impetus for a yet another investigation of Judith grows from the contention that the question of the possible purpose of Judith is still wide open for exploration. This study attempts to make a unique contribution by using a Greimassian approach to narratives, which no Judith scholar has ever attempted. This approach comprises three levels of analysis: the figurative, the narrative and the thematic. This article focuses only on the narrative level, particularly the actantial model of the story. This article contends that following the study of the actantial model of Judith, it becomes clear that the Judith narrative was aimed at revitalising Jewish religious patriotism during the difficult times of the Second Temple period.
\end{abstract}

Keywords: Actantial Model, Judith, Greimassian Perspective, Second Temple Period and Jewish Religious Patriotism

\section{A INTRODUCTION AND PROBLEM}

Judith $^{1}$ describes how an Israelite woman (also called a Jewish heroine) ${ }^{2}$ paves the way for her people's victory over an invading Assyrian army by first deceiving and then decapitating the leader of the enemy host, whom she seductively reduced to drunken unconsciousness, ${ }^{3}$ (see also White). ${ }^{4}$ Judith consists of two halves; these two halves are traditionally called Part I (1-7) and Part II

* To cite: Risimati S. Hobyane, "Actantial model of Judith, A Key to Unlocking its Possible Purpose: A Greimassian Contribution," OTE 28, no 2 (2015): 371-394. DOI: http://dx.doi.org/10.17159/2312-3621/2015/v28n2a9

In this study, Judith (italicised) refers to the book of Judith and whilst Judith (nonitalicised) refers to its female protagonist or character.

2 Carey A. Moore, "Why Wasn't the Book of Judith Included in the Hebrew Bible?" in No One Spoke Ill of Her (ed. James C Vanderkam; SBLEJL 2; Atlanta, Ga.: Scholars, 1992), 61-71.

3 Philip F. Esler, "Ludic History in the Book of Judith: The Reinvention of Israelite Identity?" BibInt 10/2 (2002): 107-143.

4 Sidnie A. White, "In the Steps of Jael and Deborah: Judith as Heroine," in No One Spoke Ill of Her (ed. James C Vanderkam; SBLEJL 2; Atlanta, Ga.: Scholars, 1992), 5-16. 
(8-16). Part I is the story of a developing religious crisis facing Israel ${ }^{5}$ and Part II is the story of how God saves Israel by the hand of a woman, Judith. ${ }^{6}$

Judith studies have been dominated primarily by historical critical approaches until fairly recently. ${ }^{7}$ Moore ${ }^{8}$ provides an insightful outline of various scholarly views on the study of the purpose of Judith dating from as early as 1888. Many of these contributions followed the historical critical approach in their analysis of the story. Similarly, with regard to the investigation of the genre of the book, a wide range of opinions is available (see Carey Moore). ${ }^{9}$ Their investigation of the purpose and genre of Judith revolved mainly around authorship and the historicity of the book.

Kanonge $^{10}$ asserts that scholars are investigating the Apocrypha ${ }^{11}$ more frequently. He further indicates that the focus in apocrypha scholarship has shifted from establishing the original texts to further studies, including employing various approaches of analysis to investigate the meaning and the possible purpose and various aspects of the texts. Under this new development on apocrypha scholarship, the Judith narrative has also attracted the interest of various scholars using various approaches to investigate its meaning. ${ }^{12}$ Although numerous articles have been written on Judith, it is beyond the scope of this article to discuss each one of them. However, this article applauds these contributions. A few recent publications attempt to establish the possible purpose of Judith and are therefore worth mentioning. They are those of Jordaan, ${ }^{13}$

5 George W. E. Nickelsburg, Jewish Literature between the Bible and the Mishnah (Minneapolis: Fortress Press, 2005), 97.

6 Daniel J. Harrington, Invitation to the Apocrypha (Grand Rapids: Eerdmans Publishing Company, 1999), 27.

7 Helen Efthimiadis-Keith, The Enemy is Within (BibInt 67; Boston: Brill Academic, 2004), 25.

8 Carey A. Moore, Judith: A New Translation with Introduction and Commentary (New York: Doubleday, 1985), 76-77.

9 Moore, Judith, 76-77.

10 Dihck M. Kanonge, "The Emergence of Women in the LXX Apocrypha" (D.Litt. et Phil. diss., North-West University, 2012).

11 The term "Apocrypha" (or "deuterocanonical books" in Roman Catholic usage) is popularly understood to describe the fifteen books or parts of books from the preChristian period that the Roman Catholic, Orthodox and Eastern churches accept, wholly or partially, as canonical Scripture, but Protestants and Jews do not (Moore, Judith, 31.

12 Efthimiadis-Keith, Enemy, 93.

13 Pierre J. Jordaan, "Reading Judith as Therapeutic Narrative," in Septuagint and Reception (ed. Johann Cook; VTSup 127; Leiden: Brill Academic Supplements, 2009), 331-442. 
Hobyane, “Actantial Model of Judith,” OTE 28/2 (2015): 371-394

Jordaan and Hobyane ${ }^{14}$ and Cornelius ${ }^{15}$ and they are directly relevant to the main focus of this article (see Hobyane ${ }^{16}$ for a detailed discussion).

While acknowledging and appreciating this shift of focus in apocrypha scholarship, this article contends that the investigation of the possible purpose of Judith is still wide open for exploration. The central hypothesis here is that the study of the actantial model of Judith, as informed by the Greimassian approach, brings yet another unique way of understanding the possible purpose of Judith.

In brief, this article argues that following the actantial model, that is, the study of the relation between actants in the narrative, the reader can establish the main object of quest in the story, in other words the main purpose of the narrative.

\section{B APPROACH OF ANALYSIS}

\section{The Actantial Model}

The actantial model is the best known and the most quoted element of Greimas' theory. ${ }^{17}$ Neemann ${ }^{18}$ asserts that the main role of the actantial model is to reveal different functions of actants in a narrative. It consists of six functions called actants, that is, addresser and addressee; subject and object; helper and opponent. ${ }^{19}$ An actant is not a character, but a unit of the narrative grammar. Characters belong to the figurative level, while actants belong to the narrative analysis. An actant can be a human being, an abstraction, a collective character or an animal. ${ }^{20}$ A character can assume different actantial functions. An actant is an antactant when his action is opposing the action of another actant. The configuration of the actantial model and the relation between actants are the main aspects of the actantial model and are discussed below.

14 Pierre J. Jordaan and Risimati S. Hobyane, "Writing and Reading War: Rhetoric, Gender, and Ethics in Judith," EkkPh 91 (2009): 238-247.

15 Elizabeth M. Cornelius, "The Interpretation of the Rhetorical Power of the Genre of Judith," APetB 20 (2009): 417-425.

16 Risimati S. Hobyane, “A Greimassian Semiotic Analysis of Judith” (D.Lit. et Phil. Diss., Northwest University, 2012).

17 Joerges B. Czamiauska and Pasquale Gagliardi, Narratives We Organize, (Amsterdam: John Benjamin Publishing House, 2003), 41.

18 Harold Neemann, Piercing Magic Veil: Toward a Theory of the Conte (Tubingen: Gunter Narr Verlag, 1999), 126.

19 Dihck M. Kanonge and Pierre J. Jordaan, "On the Role of Susanna in Susanna: A Greimassian contribution," HTS Teologiese Studies / Theological Studies 70/3 (2014); Art. \#1971, 7 pages; DOI: 10.4102/hts.v70i3.1971.

20 Kanonge and Jordaan, "On the Role of Susanna," 2. 
Behind the actantial model lies Greimas' contention that, like sentences, narratives have their own grammar and syntax. A story always provides an account of the quest of a subject for an object (axis of desire). The addresser communicates the longing for the object to an addressee (axis of communication); the helper assists the subject in his/her pursuit, while the opponent raises obstacles to his mission (axis of power). The main relation between actants in a narrative can thus be structured as seen in fig. 1 below; the discussion of the relation between actants in a narrative.

\section{1a The Relation Between Actants in a Narrative}

The six actants mentioned above are organised in three couples, called axes. These three axes are the axis of desire (relates to subject and object), the axis of communication (relates to addresser and addressee) and the axis of power (relates to subject and helper/opponent). Elements of each are considered briefly in more detail (see also Fig. 1 below).

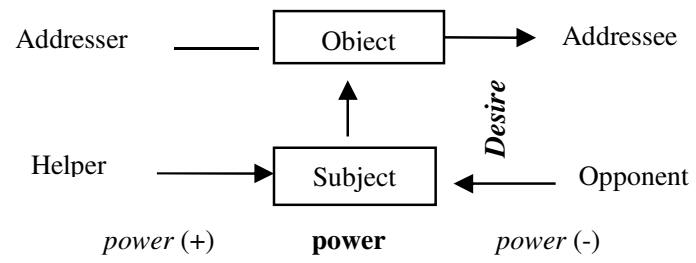

Figure 1. An actantial model illustrating different relationships between actants in the narrative

The following section briefly discusses the three axes, as outlined in Fig. 1.

\section{- The Axis of Desire: The Relation between Subject and Object}

Subject and objects are two fundamental actants. They are the sine qua non of every narrative. ${ }^{21}$ Kanonge and Jordaan ${ }^{22}$ indicate that the relation between subject and object fall on the axis of desire. In other words, "the course of a narrative is the description of the quest of the subject for the object." ${ }^{, 2}$ All other functions in a narrative are determined by their relation to the subject and the object. $^{24}$ The course of a narrative is the description of the quest of the subject for the object. ${ }^{25}$ The axis of desire examines relations between subject and object and between subject and anti-subject.

21 Anne Henault, Narratologie Semiotique Generale: Les enjeux de la Semiotique. (Paris: Press Universitaires de France, 1983), 46.

22 Kanonge and Jordaan, "On the Role of Susanna," 2.

23 Nicole Everaert-Desmedt, Semiotique du Recit (Bruxelles: De Boeck, 2007), 40.

24 Kanonge and Jordaan, "On the Role of Susanna," 2.

25 Everaert-Desmedt, Semiotique, 40. 
The relation between the subject and the object is called a narrative utterance. It can be either an utterance of state (conjunction or disjunction) or an utterance of doing (underlining the attempt of the subject to be in conjunction with the object or indicating the transition from one state to another). For a detailed discussion, see Kanonge and Jordaan. ${ }^{26}$

With regard to anti-subjects, Everaert-Desmedt ${ }^{27}$ indicates that in many cases there are two or more subjects $\left(\mathrm{S}_{\mathrm{A}}\right.$ and $\left.\mathrm{S}_{\mathrm{B}}\right)$ with opposing quests in a narrative. In this case, there is a subject and an anti-subject. An anti-subject is a subject $\left(\mathrm{S}_{\mathrm{A}}\right)$ who, in order to reach the object of his quest $\left(\mathrm{O}_{\mathrm{A}}\right)$, must frustrate the object of quest $\left(\mathrm{O}_{\mathrm{B}}\right)$ of another subject $\left(\mathrm{S}_{\mathrm{B}}\right)$. Anti-subjects appear in narratives in three different ways (Everaert-Desmedt 2007:42-43):

- Two (or more) subjects $\left(\mathrm{S}_{\mathrm{A}}\right.$ and $\left.\mathrm{S}_{\mathrm{B}}\right)$ compete to obtain the same object $\left(\mathrm{O}_{A}=\mathrm{O}_{B}\right)$. The success of $\mathrm{S}_{\mathrm{A}}$ means the failure of $\mathrm{S}_{B}$.

- Two subjects $\left(\mathrm{S}_{\mathrm{A}}\right.$ and $\left.\mathrm{S}_{\mathrm{B}}\right)$ take each other as objects: The success of one is the failure of the other.

- A subject $\left(\mathrm{S}_{\mathrm{A}}\right)$ takes as object $\left(\mathrm{O}_{\mathrm{A}}\right)$ another subject $\left(\mathrm{S}_{\mathrm{B}}\right)$ who pursues another object $\left(\mathrm{O}_{\mathrm{B}}\right)$. In engaging in the pursuit of another object $\left(\mathrm{O}_{\mathrm{B}}\right)$, the subject $\left(\mathrm{S}_{\mathrm{B}}\right)$ refuses to be the object of $\left(\mathrm{S}_{\mathrm{A}}\right)$, and therefore is opposed to the quest of $\left(\mathrm{S}_{\mathrm{A}}\right){ }^{28}$

- The Axis of Communication: Addresser and Addressee

The addresser imparts the object to the addressee. His/her mission includes three roles:

- $\mathrm{He} / \mathrm{she}$ is called subject of state: he/she longs for the object.

- He/she is said to be a subject manipulator: he/she makes the subject act by transmitting to him/her modalities for the acquisition of the object (knowledge and/or duty).

- He/she is called subject adjudicator: he/she represents desired core values in a narrative.

\section{- The Axis of Power: Helper, Subject and Opponent}

The last couple acts on the subject, either to help them reach their goal or distract them from achieving it. An anti-subject is always an opponent, but not all

26 Kanonge and Jordaan, "On the Role of Susanna," 2.

27 Everaert-Desmedt, Semiotique, 42.

28 Kanonge and Jordaan, "On the Role of Susanna," 2-3. 
opponents are anti-subjects. ${ }^{29} \mathrm{~A}$ helper of the subject can also have an opponent in the story.

\section{THE CONFIGURATION OF JUDITH'S ACTATIAL MODEL}

According to Martin and Ringham, ${ }^{30}$ all narratives consist of six key actantial roles or functions, arranged in three sets of binary opposition, namely: addresser/addressee, subject/object, and helper/opponent (see also Greimas). ${ }^{31}$ Together, the six actants and their organisation account for all possible relationships within a narrative and within the sphere of human action in general. ${ }^{32}$ Adding to this, Kanonge ${ }^{33}$ states that a story always gives an account of the quest of a subject for an object (axis of desire). He further indicates that the addresser communicates the longing for the object to an addressee (axis of communication); the helper assists the subject in his/her pursuit, while the opponent raises obstacles to his/her mission (axis of power). Therefore, the function of the addresser is to make the addressee do something, thereby turning the addressee into a subject. ${ }^{34}$ The Judith narrative is no exception to this theory. In the view of the Jewish people/religion, God is the addresser. ${ }^{35}$

This article observes that Judith has a dual actantial organisation. It has actants and antactants. This section is devoted to investigating this point. There is, in Judith, an addresser and anti-addresser, a subject and anti-subject, and an object and anti-object.

The first actantial model could therefore focus on God as the addresser, Jewish religion as the object and Judith as the subject.

The actantial organisation of Judith focusing on God as the addresser and Jewish religion as object of quest has the following configuration:

29 Kanonge and Jordaan, "On the Role of Susanna," 3.

30 Bronwen Martin and Felizitas Ringham, Dictionary of Semiotics (London: Cassel, 2000), 19.

31 Algirdas J. Greimas, On Meaning (Minneapolis: University of Minnesota Press, 1987), 107-108.

32 Martin and Ringham, Dictionary, 19.

33 Kanonge, "Emergence," 46-47.

34 Martin and Ringham, Dictionary, 19.

35 Hobyane, "A Greimassian Semiotic," 94. 


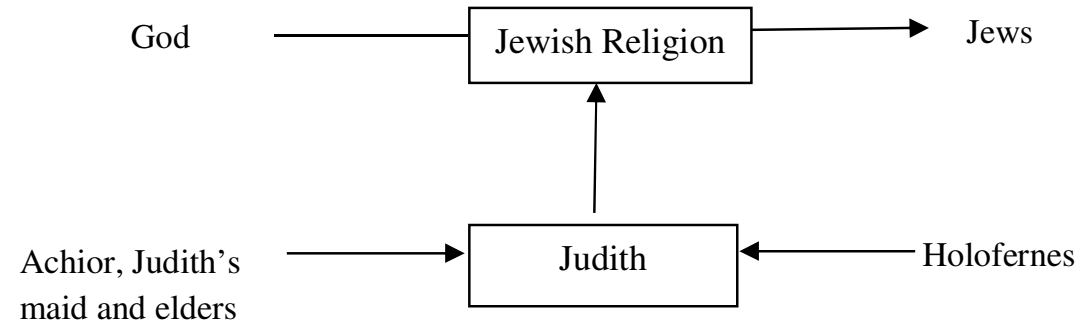

Figure 2. The actantial model of Judith focusing on Judith as the subject, God as the addresser and religion as main obiect of quest in the narrative.

The actantial organisation illustrated in Fig. 2 reveals that religion seems to be the central object of value in Judith. According to 4:3, Holofernes' threats to the Jewish people/religion come after the children of Israel had just returned from the captivity and all the people of Judea were lately gathered. The temple and the altar were sanctified after the profanation. Following the Assyrian threat and the fear of a possible destruction of the temple and the profanation of the sanctuary, the Israelites prepare themselves for war. ${ }^{36}$ The war preparation for the Israelites (4:8-15) involves prayers and acts of penance. Nickelsburg ${ }^{37}$ argues that this kind of response (prayers and acts of penance) proves to be more effective than the military response. He further indicates that from the history of Israel, one can see that Israel's strength does not come from their armies, but from their God.

Israel's dependence on God for strength is a critical point to note in Judith. It sets a clear distinction between them and the Assyrians. The Israelites depend on Kúplos $\delta$ Esòs I $\sigma$ pand (the Lord God of Israel) (addresser) for strength, while the Assyrians trust in their own strength, or perhaps they trust in Nebuchadnezzar's army (anti-addresser). The text confirms that the Israelites' prayers have a greater impact than their military endeavours. God shows con-

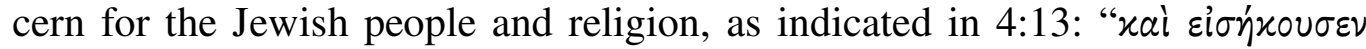

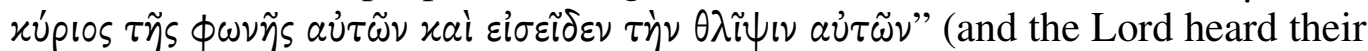
prayers and looked upon their affliction). Harrington ${ }^{38}$ contends that Israel's dependence on God for victory entails that the struggle in Judith is ultimately theological.

By proclaiming Nebuchadnezzar as the only god to be worshipped and by threatening to destroy the Jews and their religion (temple and sanctuary), Holofernes adds a spark for a religious contest in the story. Holofernes' reli-

\footnotetext{
36 Harrington, Invitation, 32.

37 Nickelsburg, Jewish Literature, 99.

38 Harrington, Invitation, 32
} 
gious claims regarding Nebuchadnezzar contrast sharply with the fundamental tenets of the Jewish religion; hence the conflict in the story.

The introduction of Judith heralds the dawn of hope and rescue for the Jewish religion. Contrary to the conduct of the elders of Bethulia who lack faith in God, ${ }^{39}$ the figure of Judith represents, more than anything else, the desired standard of Jewish religious patriotism. The author constructed the character of Judith as a widow, ${ }^{40}$ wise and a pious woman on whom the people of Bethulia could rely. She was intentionally endowed with these qualities to serve a religious motive, as Enslin also concedes. ${ }^{41}$ Immediately after she addresses the elders and the people of Bethulia, the people ask her to pray to God to bring

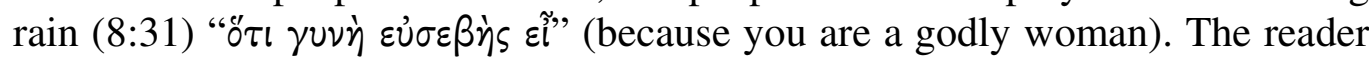
notes that this request and her earlier summoning of the elders elevate Judith from being just a woman in the community to being a leader and a subject in the narrative. In all her endeavours to save her people and the Jewish religion, Judith turns to God for help. She shows total commitment to the Jewish God and the Jewish religion and the God of Israel is with her, as Craven also asserts. $^{42}$

Judith's resilience against the Assyrians stems from her total commitment to God. By challenging Holofernes' quest and his army, Judith automatically becomes their opponent in the actantial model (Fig. 2). Achior, ${ }^{43}$ the elders and Judith's maid together act as Judith's helpers. Holofernes' failure results from Judith's fear of God. She avoids falling for Holofernes' schemes because she fears God.

A second possibility of representing Judith's actantial model focuses on the one hand, on Nebuchadnezzar as the anti-addresser. Otzen ${ }^{44}$ observes that Judith 1-3: presents Nebuchadnezzar as god and demonstrates what he is capa-

39 White, "In the Steps," 7.

40 Amy-Jill Levine, "Sacrifice and Salvation: Otherness and Domestication in the Book of Judith," in No One Spoke Ill of Her (ed. James C Vanderkam; SBLEJL 2; Atlanta, Ga.: Scholars, 1992), 20, emphasizes that Judith had to be a widow - that is, sexually experienced but unattached - in order for her to carry out her plan.

41 Morton S. Enslin, The Book of Judith: Greek Text with an English Translation: Commentary and Critical Notes (JAL; Leiden: Brill, 1972), 1.

42 Toni Craven, "The Book Of Judith In The Context Of Twentieth-Century Studies Of the Apocryphal/Deuterocanonical Books," CBR 1/2 (2003): 187-229.

43 This article observes that in the greater scheme of things Achior turns out to be Judith's helper, but not in the same sense that the maid is Judith's helper. After all, Judith and Achior do not meet until later in the narrative. However, the actantial role of Achior in the narrative justifies the stance of this study to regard Achior as Judith's helper. This point is discussed briefly later (Relations between Actants and Antactants in Judith).

44 Benedikt Otzen, Tobit and Judith (London: Sheffield Academic Press, 2002), 7072. 
ble of doing. Holofernes on the other hand, is the anti-subject and religious claims $^{45}$ as their object of quest. The second actantial model designating Nebuchadnezzar as the anti-addresser and Assyrian cult versus Jewish religion as object of quest has the following configuration:

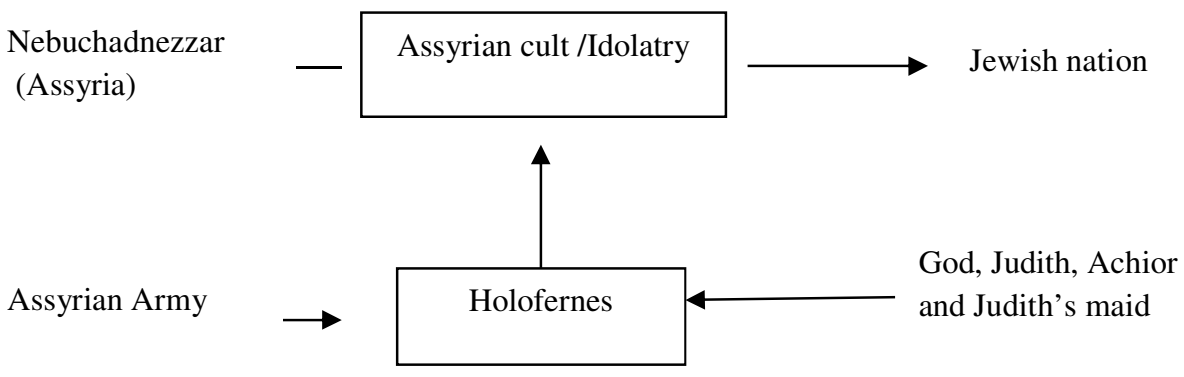

Figure 3. The actantial model of Judith focusing on Nebuchadnezzar as the antiaddresser, Holofernes as the subject and religion as main object of quest in the narrative

The second actantial model (Fig. 3) shows that, apart from actants, there are also antactants in Judith. These antactants pursue a programme opposed to that of the actants, as illustrated in Fig 2. Nebuchadnezzar's quest is to have all the Jews submitting/worshipping to him, as he says in 2:7 "And you will proclaim to them to have earth and water prepared."46 The second actantial model underlines destruction and Assyrian religious propaganda as the pursuit of Holofernes and his army. Their inspiration is the commission of their god and master, Nebuchadnezzar. Therefore, in the second actantial model, Nebuchadnezzar is the anti-addresser. If the Lord God of Israel is the addresser (in the Jewish point view); then Nebuchadnezzar is the anti-addresser.

The quest of the second configuration, that is, from the Assyrian point of view, is to destroy the Jewish religion and replace it with the Assyrian cult as the alternative religion for Jewish people. Holofernes and his army (4:1-3) are about to plunder Jerusalem, the temple, and the sanctuary. In this second actantial model, God, the elders, Achior and Judith are the opponents of the entire Assyrian nation in general, Nebuchadnezzar and Holofernes in particular. These two opposing camps in the narrative are critical. Martin and Ringham ${ }^{47}$ support this view, indicating that semiotics takes as its fundamental premise that there can be no meaning without difference/opposition in the narrative. The narrative syntax in the story of Judith proves this claim. The quest for Holofernes and the Assyrian army is to put Nebuchadnezzar in the position of the

45 The object of quest for Nebuchadnezzar and Holofernes will, therefore, be the promotion of the Assyrian cult at the expense of the Jewish religion.

46 Mark S. Caponigro, "Judith, Holding the Tale of Herodotus," in No One Spoke Ill of Her (ed. James C. Vanderkam; SBLEJL 2; Atlanta, Ga.: Scholars, 1992), 47-59.

47 Martin and Ringham, Dictionary, 7. 
Lord God of Israel. This quest is the exact opposite of what the Jewish religious patriots such as Judith, the elders, and later Achior are required to observe, as taught in the law of Moses, for example, Exod 20:1-6 (LXX). The opposition outlined above is also noticeable when investigating the relationship between actants and antactants in Judith.

\section{Relations between Actants and Antactants in Judith}

The two schematic representations (Fig. 2 and 3) depicted in the section above show that all six actants of the Greimassian model are identifiable in the story of Judith. These six actants, namely, addresser and addressee, subject and object, helper and opponent are discussed here in detail.

\section{- Addresser and Addressee}

The story of Judith starts with a depiction of the destruction of all the western nations and the crisis facing the children of Israel (1:1-4:3). In the process of defending the Jewish religion, the text indicates two manners of prayer from the Jewish community. First, the Israelites cry out to God with desperation and fear (4:9). Secondly, and contrarily to the prayers of desperation, Judith's prayer illustrates hope and faith in God (9:1-14). In both these ways of prayer, the text indicates that the people of Israel do not rely on anyone else except God. The narrative ends with people praising and worshipping God in Jerusalem $(J d t 16)$ in acknowledgement of God's salvation of them and their religion. The Lord God of Israel is revealed as the one steering the survival of the Jewish people/religion. The narrative seems to suggest that God is the one who is mostly worried about the state of the Jewish people/religion, and the addressees are performing to the glory of his name. Therefore, the communication of the Lord God of Israel as the addresser, to the Jewish people has the following structure:

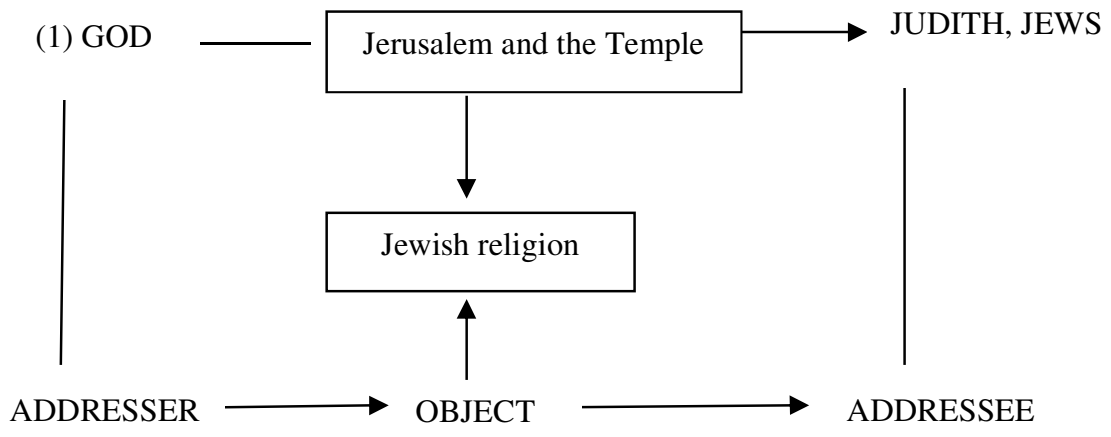

Figure 4. God's communication of the importance of the Jewish religion to the Jews

Fig. 4 shows the narrative utterance (the relationship/function) that exists between two narrative actants, namely: addresser and addressee or sub- 
ject and object. This narrative utterance can be illustrated in the following configuration:

\section{GOD $\longrightarrow$ JEWS (Judith) $\wedge$ JEWISH RELIGION}

Figure 5. The function of the narrative utterance underlying the involvement of God as the Addresser in Judith

Fig. 5 shows that God is the one who makes the situational transformation of the Jewish people/religion possible. The evidence of God's involvement in Judith is shown in two ways; namely: through the narrative utterance and His intervention/manipulation. ${ }^{48}$ First, with regard to the narrative utterance, the configuration provided above suggests that Judith can be viewed as the message from the Lord God of Israel to the Jews of the Second Temple period. The narrative utterance constitutes God's relationship with the addressee. Following the text's report in $4: 13^{49}$ and Judith's words in $13: 7,{ }^{50}$ the narrative utterance may be summarised as follows: God inspires the Jewish people (Judith, in particular) to counter idolatry and maintain the existence of the Jewish people/religion.

The Jewish people had to respond positively to this message. The character of Judith is a good example of how to respond to this message. Her role in the narrative illustrates what it means to be a true Jewish religious patriot or a

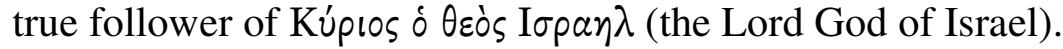

In summarising the narrative utterance in Fig. 5, the study shows that God is the addresser, the Jewish community assumes the role of addressee, and the Jewish religion is the main concern in the narrative (object of quest).

Secondly, God's involvement in Judith is evident from his manner of intervention/manipulation in the story. Manipulation ${ }^{51}$ denotes the action of the addresser on the addressee to make him/her act. It is synonymous with the word "causation" or "cause to do." The reader sees God as the pillar of strength behind the actions of Judith and the entire Jewish community. This manner of involvement implies that God assumes all three traditional functions of the addresser. He appears in the story as a subject adjudicator, a subject manipulator and a subject of state. God, as a subject of state is different from the char-

48 In accordance with the Greimassian tradition, the word "manipulation" is a technical term. There is, of course, no connotation of dishonesty or deception as in the more popular usage of the term.

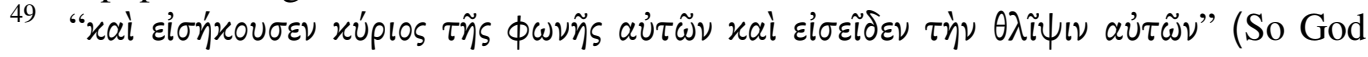
heard their prayers, and looked upon their afflictions).

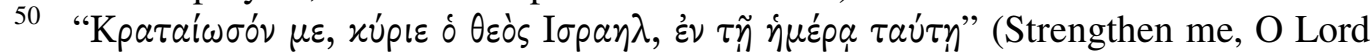
God of Israel, this day).

51 See also Kanonge, "Emergence," 51. 
acter Judith, the subject performer (also known as a subject of doing). ${ }^{52}$ God is himself interested in preserving the Jewish people/religion. Israel and the Jewish religion are his own inheritance, as mentioned in 9:12. It may be argued that the role assumed by the subject and her helpers is the mission that God would have accomplished himself if he was directly involved as a human character in the story, as supported by $(9: 11)$.

The song of praise in Jdt 16 shows that God is an active participant in the process of the survival of the Jewish religion, even if he is not an active character in the narrative. The expression "inactive character" should not be confused with an act of intervention. God is an inactive character in the sense that he does not speak or give orders as he does in Joshua 1 and many other Biblical narratives. However, the reader notes that he is the source for transformation in the Judith narrative.

According to Kanonge ${ }^{53}$ the expression "cause-to-do" characterises the action of the addresser on the future subject. On the semiotic square, this expression offers four different modes of manipulation, which may be illustrated as follows:

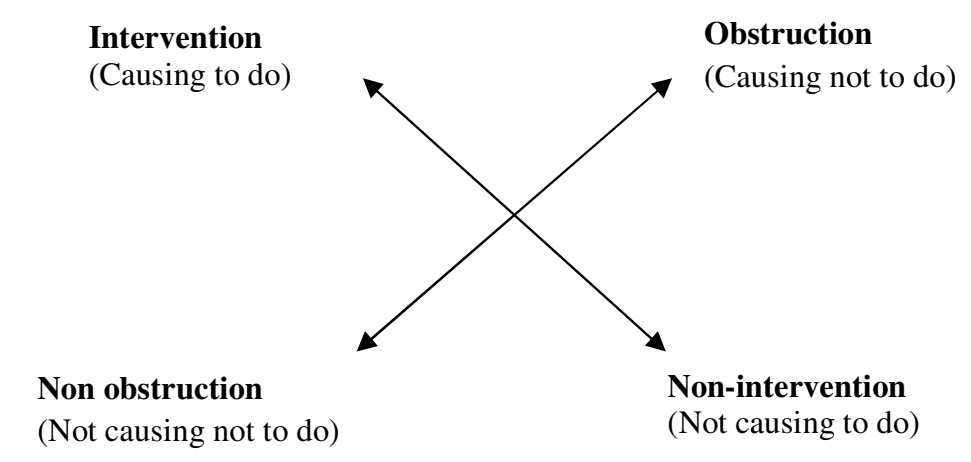

Figure 6. The four possible aspects of the manipulative actions of Kúplos $\delta \theta \varepsilon \dot{s} \operatorname{I\sigma pa\eta \lambda }$ (the addresser) on the addressee in a narrative

Intervention, non-intervention, obstruction and non-obstruction illustrate the action of the addresser in the narrative. Judith is an appropriate narrative to investigate the influence of the addresser in this way. God's action in the Judith narrative is in accordance with these four aspects of manipulation. It is beyond the scope of this article to discuss all forms of manipulation in detail. However, a few aspects are pointed out to clarify the occurrence of each manipulation in the story.

\footnotetext{
52 Martin and Ringham, Dictionary, 127.

53 Kanonge, "Emergence," 143.
} 
First, the fact that God hears and answers the prayers of the Israelites signifies his intervention and concern as the helper of Israel in times of trouble (5:13). Throughout the history of Israel, God has always revealed himself as their helper, when his people call upon him for help. The story of Moses and the burning bush in Exod 3:1-22, vv. 7-10 in particular, is a good example of this, as Efthimiadis-Keith ${ }^{54}$ also observes. This text mentions that God heard the cries of the Hebrews and has seen their misery during their Egyptian oppression.

The petition of Judith in 9:4 and 12 resembles the same understanding about God.

Second, the introduction of Judith can itself be seen as God's indirect intervention to rescue the Jewish religion from impending doom. One may argue that God causes Judith to stand up for the Jewish religion. God works with the Israelites in this way in times of crisis, for example in Additions to Daniel (History of Susanna ${ }^{55}$ - Theodotion); God raises the spirit of Daniel in Sus 45 to rescue Susanna and to expose the elders in their lawless adventures.

Furthermore, other aspects of God's causation in the narrative enter into play. The aspect of non-intervention can also be drawn from the text. God does not explicitly cause (command) Judith to leave her people and go into the enemy's camp. Neither does God stop Judith from going out, nor does he warn her of the danger of the possible ungodly (idolatry and sexual immorality) influence of the Assyrians. It is evident that there is also a laissez faire (not causing not to do) in the sense that there is no obstruction here. According to Kanonge, ${ }^{56}$ laissez faire is "a refusal to interfere in other people's affairs or the practice of letting people do as they wish." The going out of Judith seems to be her voluntary action in which God's active intervention is not visible.

The banishment of Achior from the Assyrian camp leaves more to be said in terms of God's causation in the story. After Achior gives his advice to Holofernes, all the people (Assyrian army) standing around the tent of Holofernes call strongly for Achior's death. This strong suggestion seems to be a general feeling of consensus within the Assyrian camp.

The evil scheme (sexual immorality) of Holofernes against Judith is another point worth mentioning. God does not tell Holofernes to plan this, nor does he stop him. After all his efforts to seduce Judith, Holofernes' plan does not succeed. Judith manages to stay for four days in the midst of potentially dangerous men in the Assyrian camp without anything bad happening to her.

54 Efthimiadis-Keith, Enemy, 182.

55 In this article, Susanna (italicised) refers to the book of Susanna and whilst Susanna (non-italicised) refers to its female protagonist or character.

56 Kanonge, "Emergence," 144. 
The role of Kúplos $\delta$ Esòs I $\sigma p a \eta \lambda$ (the Lord God of Israel) as protector comes to the fore. He prevents evil from happening to his people. As a result, Judith declares that the Lord played a role in the obstruction of the enemy to defile her (13:16).

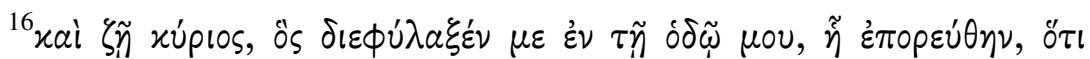

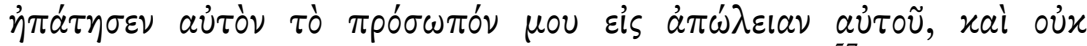

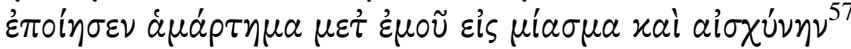

When the scene of Judith and Holofernes in Holofernes' tent unfolds, Judith brutally kills Holofernes (13:8-9). God does not explicitly command the killing of Holofernes. Neither does God object to the act of killing. Here again, there is, from God's perspective, a laissez faire (not causing not to do), that is, non-obstruction.

The aspect of non-obstruction also comes into play with regard to the going out of the Assyrian army in the beginning of the story. God does not obstruct this army to go out, even though they would soon become a danger to the existence of the Jewish people/religion (his covenantal people). It may therefore be deduced that from a careful reading of Judith, one can conclude that God does participate actively in the story, even if he rarely plays a role as a character. A reader can see the involvement of the God of Israel everywhere in the story. God's causative action controls events and circumstances throughout the story. His direct intervention, non-intervention, obstruction, as well as his not-causing-not-to-do, serves his design. ${ }^{58}$

As already shown above, God is not the only addresser in the story. The actantial schema (Fig. 3) showed that there is also an opposing addresser or anti-addresser in the story, namely Nebuchadnezzar. The anti-addresser "not only institutes a system of values that opposes the original quest, but also attempts to manipulate the receiver/subject to act in a way contrary to the desires of the first addresser." ${ }^{59}$ This study observes that even though Holofernes did not know what the God of Israel was planning through Judith, his role in the narrative clearly pushes the agenda of Nebuchadnezzar. His desire to seduce Judith is contrary to the desire of the God of Israel, who expects Judith to stay away from sexual immorality (13:16).

The Jews undergo two opposing manipulative actions from the Lord (mainly through the subject Judith) and from Nebuchadnezzar (through the anti-subject, Holofernes). Nebuchadnezzar represents an ideology that is

57 As the Lord lives, who has kept me in my way that I went, my countenance has deceived him to his destruction, and yet has he not committed sin with me, to defile and shame me.

58 Kanonge, "Emergence," 145.

59 Martin and Ringham, Dictionary, 25. 
completely opposite to the Jewish faith centred on the Law of Moses in Exod 20:3 (LXX).

The two opposing systems of values can be illustrated on the semiotic square as follows:

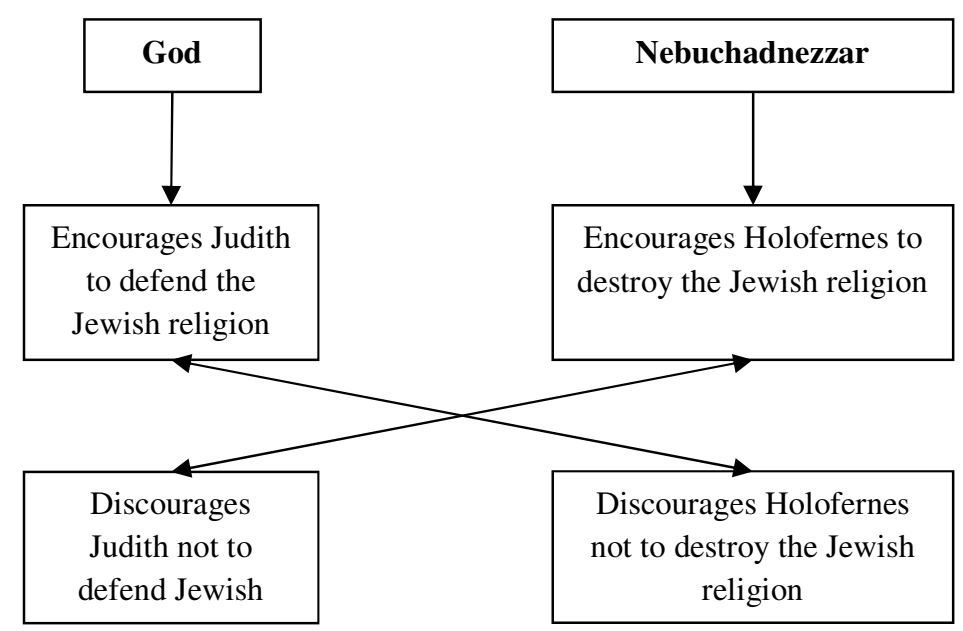

Figure 7. The illustration of the twofold action of manipulation of Jews and the Assyrians, by God and by Nebuchadnezzar (The Assyrian king) respectively

Fig. 7 can be divided into two distinct schemas to show the two main transformations in the Judith narrative. Both transformations highlight the manipulative actions of the addressers, namely God and Nebuchadnezzar, on the addressee (Jewish community).

First, the function of transformation underlying God's action on Judith appears as follows:

\section{F [God $\longrightarrow$ (Judith V Jewish Religion)]}

\section{Figure 8. The function of transformation underlying God's action on Judith} concerning the Jewish religion

The function of transformation in Fig. 8 illustrates the result of God's manipulative action on Judith from her introduction in the story to the end of the story. This study observes that God succeeds $(\mathrm{V}=$ mission accomplished/state of conjunction) in his endeavour to strengthen Judith (as

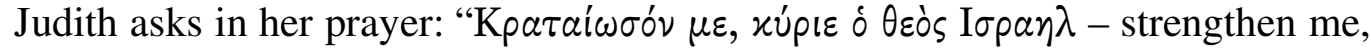
O Lord God of Israel" in 13:7) to defend the Jewish religion until the end of the story. 
On the other hand, Nebuchadnezzar's influence on Holofernes has the following configuration:

\section{F [Nebuchadnezzar $\longrightarrow$ (Holofernes $\Lambda$ Jewish religion)]}

Figure 9. The function of transformation underlying Nebuchadnezzar's action on Holofernes concerning the Jewish religion.

The function of transformation in Fig. 9 represents the manipulative action of Nebuchadnezzar on Holofernes against the Jews. The main aim of the action is to have the Jews surrender their religion and follow Nebuchadnezzar as god. This action would see the Jews committing a sin of idolatry before their God, following Exod 20:3. However, the unfolding of the story reveals that this endeavour by Nebuchadnezzar fails completely $(\wedge=$ mission not accomplished/disjunction) as Judith decapitates Holofernes and eventually overthrows the Assyrian army before executing their evil plan concerning Bethulia and Jerusalem.

The schema provided below represents the confrontation of the two manipulative actions aimed at Jews at the end of the narrative:

F [Nebuchadnezzar $\rightarrow($ Holofernes $\Lambda$ Jewish religion $)]$

$\Longrightarrow$ F [God $\rightarrow$ (Judith V Jewish Religion)]

Figure 10. The function of transformation representing the confrontation of the two addressers (God and Nebuchadnezzar) on Jews.

As indicated above, Fig. 10, God's endeavour succeeds against Nebuchadnezzar's attempt to dissuade Jews from defending their religion. Thus, God (addresser) conquers Nebuchadnezzar (anti-addresser). This section explored this intricate relationship between the addressers and addressees in the narrative. The next section investigates the interaction between the subject and object.

\section{- Subject and Object}

The relation subject/object in Judith is twofold: both Judith and Holofernes are opposing subjects, and their central object of quest is religion. Holofernes and Judith are thus objects of one another.

While keeping in mind Judith's central object of quest (Jewish religion), a reader should recognise, on the one hand, that Judith's main reason for coming to the Assyrian camp is to kill Holofernes, even if the text does not explicitly state this objective. Judith does not state this objective either; she only mentions that she is going to go down and show the Jews how God will deliver them before/within the time of ultimatum. Here Holofernes is an object of Judith's plan. On the other hand, when Judith arrived in the Assyrian camp, 
Hobyane, “Actantial Model of Judith,” OTE 28/2 (2015): 371-394

she is a soft target for Holofernes' sexual agenda. Therefore, from Judith's perspective, the main purpose is to defend and to maintain the Jewish religion by decapitating Holofernes and thereby nullifying the strength of the Assyrian army.

The opposite is the case with Holofernes; his goal is to overthrow the Jewish people/religion and impose the Assyrian cult as the religion of the people. Conquering Judith sexually is a microcosm of conquering the Jewish people/religion and their God, since she comes as their God's representative.

Following the argument above, both Holofernes' and Judith's quests can be illustrated respectively as follows:

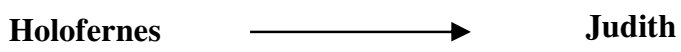

Figure 11. Relation between the subject and the object underlying Judith as the object of Holofernes' quest

On the other hand Judith's quest may be illustrated as:

\section{Judith $\longrightarrow \quad$ Holofernes}

Figure 12. Relation between the subject and the object underlying Holofernes as the object of Judith's quest.

The function representing the mission of these two subjects (Judith and Holofernes) has the following structure, focusing, on the one hand, on Holofernes' quest:

(Holofernes $\Lambda$ Judith)

(Holofernes $\Lambda$ Judith)

Figure 13. The relation between Holofernes and Judith underlying the failure of Holofernes in his quest at the end of the narrative.

Figure 13 shows that Holofernes' pursuit to destroy the Jewish religion (even to conquer Judith sexually), fails. Holofernes, therefore, goes from the initial state of disjunction to the final state of disjunction. The state at the end is the same as that at the beginning. This means that Holofernes achieves nothing in his quest.

On the other hand, Judith's quest would appear as follows:

\section{Judith $\longrightarrow$ Holofernes $\longrightarrow$ Jewish religion}

Figure 14. The relation between the subject and the object underlying Judith as the subject and the Jewish religion as her object of quest

Fig. 14 also represents the collective desire of the entire people of Bethulia and Jerusalem. However, Judith takes up a leading role as the main subject in achieving the desired outcome. In summary, the function representing Judith's quest would appear as follows: 


\section{Judith $\Lambda$ Jewish religion $\longrightarrow$.Judith $\vee$.Jewish religion}

Figure 15. The relation between Judith and the Jewish religion underlying Judith's success in her quest at the end of the narrative

Even though Judith does not mention her plan of saving her people explicitly, the reader can deduce from the text in 8:32 that her modus operandi is killing for the sake of the Jewish religion. As DeSilva ${ }^{60}$ puts it "Dressed to kill, she leaves Bethulia ..." The disjunction at the initial step in Fig. 15 points to the fact that the Jewish people/religion is still under threat of extinction and will remain under threat if something is not done. Judith leaves Bethulia for the Assyrian camp in an attempt to save her people and their religion and she eventually succeeds in her quest. The state at the end is not the same as at the beginning. Therefore, Judith goes from the initial state of disjunction to the final state of conjunction, as illustrated in Fig. 15.The two quests have two opposing subjects (or anti-subjects). The success of Judith is the failure of Holofernes. Put together, the two quests stand as follows:

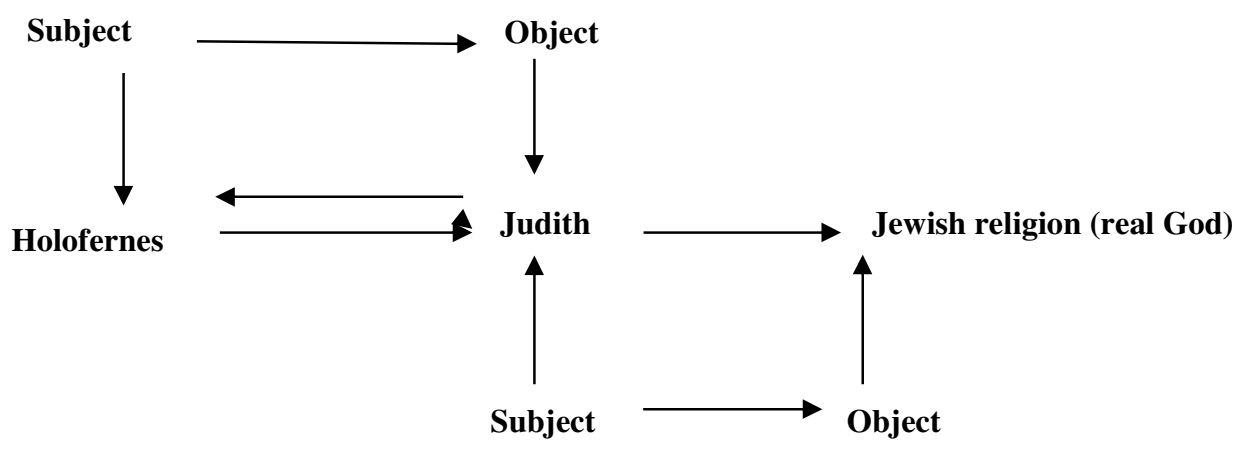

Figure 16. Schema representing the two actantial roles of both Judith and Holofernes as subjects and objects in the narrative

Fig.16 shows that Judith assumes two functions in the narrative. First, she is the object of Holofernes' quest and second, she is herself a subject in the pursuit of saving her people and defending the Jewish religion. In order to achieve her main goal, she has to defeat Holofernes first. This schema shows that an actant can assume different actantial functions in a narrative. ${ }^{61}$ The roles played by both Judith and Holofernes in the story provide the reader with a good example of this.

60 David A. De Silva, Introducing the Apocrypha (Grand Rapids, Mich.: Baker Academic, 2002), 87.

61 Kanonge, "Emergence," 149. 


\section{- Helpers and Opponents}

Martin and Ringham ${ }^{62}$ state that helpers and opponents entertain a subsidiary relationship to the subject, their function being to intervene positively or negatively in the pursuit of the goal. Thus, the desire of an object becomes the focal point of the whole scheme. Therefore, any actant that aids the subject in its quest is known as a helper and any actant who hinders the subject in its quest is known as an opponent. ${ }^{63}$ In Judith some actants contribute towards Judith's success in her mission to save her people and prove that Kúpros ó $\theta \varepsilon$ ò I $\sigma \rho \alpha \eta \lambda$ (the Lord God of Israel) is the one and only real God, while other actants (called antactants, such as Holofernes and Bagoas) attempt to counter her endeavour. This study also observes that with regard to Holofernes' quest, some actants (such as the Assyrian army, children of Esau and Bagoas) also contribute to help him succeed in his mission, while others (such as, Achior, Judith and Judith's maid) attempt to oppose his efforts. The following subsection is devoted to briefly discussing these aspects.

\section{Opponents}

Reading the story from Judith's perspective reveals that Holofernes is Judith's main opponent because he is the anti-subject in the story. Judith's determination to save her people and the Jewish religion encounters the resistance of Holofernes and his entire Assyrian army. Although Holofernes is identified as the anti-subject and the main opponent of Judith's quest, this study asserts that Holofernes is not the only character who opposes Judith in the story.

In her journey to the Assyrian camp, Judith encounters her first opposition, and that is the Assyrian patrol. They are listed among the opponents since they are Assyrians and therefore capable of harming her. However, it must be noted that this opposition does nothing to harm Judith according to the text. Instead of ill-treating Judith, they make jokes with Judith and her maid and escort them to Holofernes, ${ }^{64}$ thanks to the beauty and wisdom of Judith. The Assyrian soldiers are only too happy to escort her. They do not treat her like a prisoner of war. In fact, they may be seen as her unwitting helpers in that they take her to the very heart of the Assyrian offensive, Holofernes' tent, where she is then able to execute her plan.

Holofernes, on the other hand, left the city of Nineveh under the instructions of his master with goals to achieve, that is, to destroy the Jews and their religion and have Nebuchadnezzar recognised and served as the only god. However, some actants in the narrative oppose his endeavours too. First,

62 Martin and Ringham, Dictionary, 19.

63 Martin and Ringham, Dictionary, 97.

64 Efthimiadis-Keith, Enemy, 250. 
Holofernes encounters the resistance of the Israelites in 4:6-7. The text indicates, in 5:1, that it was later declared to Holofernes that the children of Israel are not ready to surrender their cities, but are preparing for war to defend themselves and their religion. There is, again, a conflict in the narrative. Holofernes' plan of destroying the Jewish religion encounters resistance and opposition. This article observes that Holofernes also encounters yet another opponent in the person of Achior in 5:5-21. Caponigro ${ }^{65}$ calls Achior a discouraging counsellor. Achior's speech does not only seek to discourage Holofernes but also undermines Holofernes' military and religious ideologies. Consequently, Achior is banished from the Assyrian camp and delivered to the Israelites so that he may be destroyed with them by Holofernes and his army.

Lastly, as anti-subjects against each other, Judith and Holofernes stand as opponents in their objects of quests.

\section{Helpers}

As already established in the discussion of the role of the addresser, God is revealed as the chief helper of Judith's course in the narrative. Throughout the narrative, from her introduction, Judith is connected to God through faith and prayer. The reader learns from Judith's introduction in 8:4 that she makes a tent on the top of her house, which is most probably her special place of prayer. ${ }^{66}$

The text explicitly reports in 9:11 in Judith's prayer that God is "the

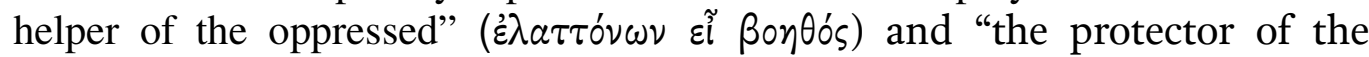

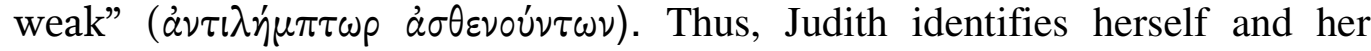
people with the weak and the oppressed. The essence of these expressions in 9:11 illustrates that God is Judith's helper. Remarkable to note, is that Judith connects God favourably to Simeon's vengeance of Dinah's rape (9:2). As God has given Simeon the sword to take vengeance against those who defiled her (Dinah), so Judith is praying to be strengthened to destroy the Assyrians. This must be done before they defile the temple and the sanctuary.

It is, however, worth mentioning that there are other actants in Judith who play a role in assisting Judith to succeed in her enterprise. Branch and Jordaan $^{67}$ call these actants "secondary characters." They are not insignificant in the story. These characters, according to Jordaan, ${ }^{68}$ are also the voice of the narrator. He speaks through them. These are characters like Achior, Judith's Maid and the elders of Bethulia.

65 Caponigro, "Judith," 48.

66 Hobyane, "A Greimassian Semiotic," 111.

67 Robin G. Branch and Pierre J. Jordaan, "The Significance of the Secondary Characters in Susanna, Judith, and the Additions to Esther in the Septuagint," APetB 20/55 (2009): 391.

68 Jordaan, "Reading Judith," 336. 
First, concerning Achior, in part I (5:5) of the story Roitman ${ }^{69}$ observe that Achior supplies "the truth concerning this people (Jewish people)." By so doing, Achior lays a foundation (5:5-21) upon which Judith later builds the deceitful argument she presents before Holofernes (11:9-10):

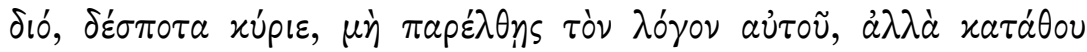

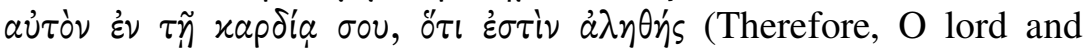
governor, reject not his (Achior) word; but lay it up in your heart, for it is true).

In part II of the story, Achior is vindicated by Judith, as Roitman ${ }^{70}$ also observes. He plays another role in Bethulia when Judith, after returning with Holofernes' head, commands that Achior be brought before her (14:5). When Achior comes before Judith, he identifies and confirms that the head that Judith brought with her indeed belonged to Holofernes. Achior's confirmation strengthens Judith's evidence before the people of Bethulia. This encounter subsequently led to Achior's conversion to Judaism. ${ }^{71}$ In summarising the role played by Achior, Roitman ${ }^{72}$ asserts that Achior is designed thematically as well as functionally as the mirror image of Judith, being the kind of double or "alter ego." In some way, the Ammonite leader is the masculine/pagan version of the feminine/Jewish Judith.

Second, the elders of Bethulia play their role as helpers in Judith's quest. The fact that they do not oppose Judith's declaration of going out to the Assyrian camp makes it fitting to regard them as helpers in the process of destroying the enemy. The elders go through a significant development in the narrative. Initially the story presents them as people who are undecided/cowards, but later, they acknowledge Judith's determination and give her their blessings. In other words, they do not remain flat characters in the story, but progress to a new level of understanding or insight (see Branch and Jordaan). ${ }^{73}$ Instead of opposing the request by Judith, they say to her in $8: 35$,

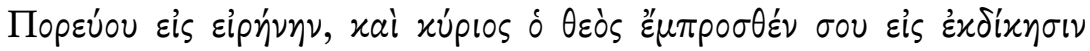
$\tau \tilde{\omega} \nu \dot{\varepsilon} \chi \theta \rho \tilde{\omega} \nu \dot{\eta} \mu \tilde{\omega} \nu$ (go in peace and the Lord God be before you to take vengeance on our enemies).

69 Adolfo D. Roitman, "Achior in the Book of Judith: His Role and Significance," in No One Spoke Ill of Her (ed. James C Vanderkam; SBLEJL 2; Atlanta, Ga.: Scholars, 1992), 31-45.

70 Roitman, “Achior," 31.

71 White, "In the Steps," 10.

72 Roitman, "Achior," 38.

73 Branch and Jordaan did not investigate the progress in understanding of the elders, but they used this concept to investigate other secondary characters in Judith narrative. 
Lastly, the role played by Judith's maid cannot go unnoticed. Branch and Jordaan ${ }^{74}$ acknowledge that the maid is essential to the plot of the story because her presence substantiates Judith's character. They point out that the maid advances the plot by her silence and through it, she supports Judith. Through her presence, she willingly risks her life for Judith and her fellow Israelites. She serves Judith by making sure that her toilette is thorough. ${ }^{75}$ Levine $^{76}$ also observes that Judith's presence and role in the narrative offers those previously marginal to or excluded from the power base - Jewish women, Achior the gentile, the main servant - roles in society and cult. Holofernes' determination and goal, on the other hand, finds support from few actants in the story. Firstly, the narrative mentions that Nebuchadnezzar and the Assyrian army are the main inspiration behind Holofernes' enterprise. Apart from Nebuchadnezzar, Holofernes has other actants who help him in the process of attempting to achieve his goals, namely: the children of Esau (they provided Holofernes with "insider information" as to how can he conquer Israel); the governors of Moab and the children of Ammon (foreign advisors of Holofernes); his servants (13:1) and Bagoas the eunuch. For a detailed discussion on these actants and how they helped Holofernes, see Hobyane. ${ }^{77}$

\section{CONCLUSION}

The endeavour of this article was to investigate the possible purpose of Judith. The article conceded and applauded various scholarly views brought forward regarding the possible purpose of Judith. However, no scholar has yet attempted to establish Judith's purpose by using the study of the actantial model, as informed by the Greimassian approach of analysis.

To bring yet another contribution to Judith scholarship, the contention here was that, following the actantial model of Judith narrative, that is, the study of the relation between actants in the narrative, the reader can established the main object of quest in the story.

The distribution of actantial roles shows that Judith has a dual actantial configuration. The first actantial configuration consists of Judith's main quest, that is, to save her people and the Jewish religion. The second actantial configuration is illustrated by Holofernes' pursuit of seeking to destroy the Jews, their cities and sanctuary and to ultimately declare Nebuchadnezzar as god alone. In this second actantial configuration, Judith is herself an object of Holofernes' sexual desire. Holofernes, as an anti-subject, is the forerunner in this quest.

74 Branch and Jordaan, "The Significance," 406.

75 Branch and Jordaan, "The Significance," 406.

76 Levine, "Sacrifice," 17-30.

77 Hobyane, "A Greimassian Semiotic," 50, 54. 
The discussion on the role of Kúpios o $\theta \varepsilon$ ò $\varsigma$ I $\sigma \rho \alpha \eta \lambda$ (the Lord God of Israel), on the one hand, has shown that $\mathrm{He}$ is the addresser and appears in the story as a subject adjudicator, a subject manipulator and a subject of state. He is, in fact, the initiator of Judith's quest to show a stern Jewish religious patriotism. On the other hand, Nebuchadnezzar (anti-addresser) plays an important role in inspiring brutality in and through Holofernes and the entire Assyrian army. It is shown that if God is the addresser, Nebuchadnezzar is the anti-addresser; and that if Judith is the subject, Holofernes is the anti-subject. Finally, unless the reader chooses to overlook the textual evidence from the narrative itself, the actantial model of Judith shows that the purpose of the story was to inspire Jewish religious patriotism amongst the Jews of the second temple period. Judith, the protagonist in the story, emerges as a subject of doing in communicating this purpose by the author.

\section{BIBLIOGRAPHY}

Branch, Robin G. and Pierre J. Jordaan. "The Significance of the Secondary Characters in Susanna, Judith, and the Additions to Esther in the Septuagint." Acta Patristica et Byzantina 20/55 (2009): 389-416.

Caponigro, Mark S. "Judith, Holding the Tale of Herodotus." Pages 47-59 in No One Spoke Ill of Her. Edited by James C. Vanderkam. Society of Biblical Literature Early Judaism and Its Literature 2. Atlanta, Ga.: Scholars, 1992.

Craven, Toni. "The Book Of Judith In The Context Of Twentieth-Century Studies Of the Apocryphal/Deuterocanonical Books." Currents in Biblical Research 1/2 (2003): 187-229.

Cornelius, Elizabeth M. "The Interpretation of the Rhetorical Power of the Genre of Judith.” Acta Patristica et Byzantina 20 (2009): 417-425.

Czamiauska-Joerges Barbara and Gagliardi Pasquale. Narratives We Organize. Amsterdam, John Benjamin Publishing House, 2003.

De Silva, David A. Introducing the Apocrypha. Grand Rapids, Mich.: Baker Academic, 2002.

Efthimiadis-Keith, Helen. The Enemy is Within: A Jundian Psychoanalytic Approach to the Book of Judith. Biblical Interpretation 67. Boston: Brill Academic Publishers, 2004.

Enslin, Morton S. The Book of Judith: Greek Text with an English Translation, Commentary and Critical Notes: Edited with General Introduction and Appendices by Solomon Zeitlin. Jewish Apocryphal Literature Series. E. J. Brill for Dropsie University, Philadephia, 1972.

Esler, Philip F. "Ludic History in the Book of Judith: The Reinvention of Israelite Identity?" Biblical Interpretation 10/2 (2002): 107-143.

Everaert-Desmedt, Nicole. Semiotique du Recit. Bruxelles: De Boeck, 2007.

Greimas, Algirdas J. On Meaning. Minneapolis: University of Minnesota Press, 1987.

Harrington, Daniel J. Invitation to the Apocrypha. Grand Rapids: W.B. Eerdmans, 1999.

Henault, Anne. Narratologie Semiotique Generale: Les enjeux de la Semiotique. Paris: Press Universitaires de France, 1983. 
Hobyane, Risimati S. "A Greimassian Semiotic Analysis of Judith.” D.Lit. et Phil. Diss., Northwest University, 2012.

Jordaan, Pierre J. "Reading Judith as Therapeutic Narrative.” Pages 331-442 in Septuagint and Reception. Edited by Johann Cook. Supplements to Vetus Testamentum 127. Leiden: Brill Academic Supplements, 2009.

Jordaan, Pierre J. and Risimati S. Hobyane. "Writing and Reading War: Rhetoric, Gender, and Ethics in Judith." Ekklesiastikos Pharos 91 (2009): 238-247.

Kanonge, Dihck M. "The Emergence of Women in the LXX Apocrypha.” D.Lit. et Phil. Diss., Northwest University, 2012.

Kanonge, Dihck M and Pierre J. Jordaan. "On the Role of Susanna in Susanna: A Greimassian contribution." HTS Teologiese Studies / Theological Studies 70/3 (2014). Art. \#1971. 7 pages. DOI: 10.4102/hts.v70i3.1971.

Levine, Amy-Jill. "Sacrifice and Salvation: Otherness and Domestication in the Book of Judith." Pages 17-30 in No One Spoke Ill of Her. Edited by James C.

Vanderkam. Society of Biblical Literature Early Judaism and Its Literature 2. Atlanta, Ga.: Scholars Press, 1992.

Martin, Bronwen and Felizitas Ringham. Dictionary of Semiotics. London: Cassel, 2000.

Moore, Carey A. Judith: A New Translation with Introduction and Commentary. Garden City, N.Y.: Doubleday, 1985.

. "Why Wasn't the Book of Judith Included in the Hebrew Bible?" Pages 61-

71 in No One Spoke Ill of Her. Edited by James C Vanderkam. Society of Biblical Literature Early Judaism and Its Literature 2. Atlanta, Ga.: Scholars Press, 1992.

Neemann Harold. Piercing Magic Veil: Toward a Theory of the Conte. Tubingen: Gunter Narr Verlag, 1999.

Nickelsburg, George W. E. Jewish Literature between the Bible and the Mishnah. Minneapolis: Fortress Press, 2005.

Otzen, Benedikt. Tobith and Judith. Guide to Apocrypha and Pseudepigrapha. London: Sheffield Academic Press, 2002.

Roitman Adolfo D. "Achior in the Book of Judith: His Role and Significance." Pages 31-45 in No One Spoke Ill of Her. Edited by James C. Vanderkam. Society of Biblical Literature Early Judaism and Its Literature 2. Atlanta, Ga.: Scholars Press, 1992.

White Sidnie A. "In the Steps of Jael and Deborah: Judith as Heroine." Pages 5-16 in No One Spoke Ill of Her. Edited by James C. Vanderkam. Society of Biblical Literature Early Judaism and its literature 2. Atlanta, Ga.: Scholars Press, 1992.

Risimati Synod Hobyane, Faculty of Theology, North-West University (Potchefstroom Campus).Email: Risimati.hobyane@nwu.ac.za. 